\title{
Reducing meat consumption in developed and transition countries to counter climate change and biodiversity loss: a review of influence factors
}

\author{
Susanne Stoll-Kleemann ${ }^{1} \cdot$ Uta Johanna Schmidt $^{1}$
}

Received: 12 June 2015/ Accepted: 28 September 2016/Published online: 6 October 2016

(c) The Author(s) 2016. This article is published with open access at Springerlink.com

\begin{abstract}
A dietary shift towards reduced meat consumption is an efficient strategy for countering biodiversity loss and climate change in regions (developed and transition countries) where consumption is already at a very high level or is rapidly expanding (such as China). Biodiversity is being degraded and lost to a considerable extent, with $70 \%$ of the world's deforestation a result of stripping in order to grow animal feed. Furthermore, about $14.5 \%$ of the world's anthropogenic greenhouse gas emissions (GHG) are calculated to be the result of (mainly industrial) livestock farming. The research reviewed here focuses on the feasibility of reducing meat consumption in developed and transition countries, as this would-among other positive effects-reduce the global loss of biodiversity, the need for unsustainable agricultural practices and GHG emissions. This article reviews the barriers, opportunities and steps that need to be taken in order to encourage the consumption of less meat, based on an interdisciplinary and multifactor approach. The evidence is gathered from a systematic metaanalysis of factors (including personal, sociocultural and external factors) that influence individual meat-eating behaviour. The most relevant factors that influence behaviour appear to be emotions and cognitive dissonance
\end{abstract}

Electronic supplementary material The online version of this article (doi:10.1007/s10113-016-1057-5) contains supplementary material, which is available to authorized users.

Susanne Stoll-Kleemann

susanne.stoll-kleemann@uni-greifswald.de

Uta Johanna Schmidt

uta.schmidt@uni-greifswald.de

1 Chair of Sustainability Science and Applied Geography, Ernst-Moritz-Arndt University of Greifswald, FriedrichLudwig-Jahn-Str. 16, 17487 Greifswald, Germany (between knowledge, conflicting values and actual behaviour) and sociocultural factors (e.g. social norms or social identity). For different factors and groups of people, different strategies are appropriate. For example, for men and older people deploying the health argument or arguing for flexitarianism (reduced meat consumption) may prove the most promising approaches, while providing emotional messages or promoting new social norms is recommended in order to address barriers such as cognitive dissonance.

Keywords Biodiversity loss - Meat consumption . Dissonance and behaviour change $\cdot$ Meta-analysis . Climate change

\section{Introduction}

We contend here that the apparent competition between diverting land to conserve biodiversity or to produce enough food worldwide would not exist if more crops were produced for direct human consumption rather than for feeding livestock (see also Avellan et al. 2010). Although strong evidence suggests that shifting diets to reduce levels of meat consumption-in developed countries where it remains at a high level (e.g. the USA and Europe) as well as in populous transition countries where meat consumption is rapidly expanding, such as China and Brazil-is a key leverage point for tackling climate change and biodiversity loss (Gerber et al. 2013; Joyce et al. 2012; Machovina et al. 2015; Meier and Christen 2013) some still argue in favour of agricultural intensification and expansion as an essential process to feed all people in the future (see e.g. Cassman 1999; Tilman et al. 2011). Besides the importance of reducing total calorie intake for GHG mitigation (Masset et al. 2014; Vieux et al. 2013), reduced 
meat consumption would be one vital element of a longterm path towards a more sustainable and just world (Foley et al. 2011; Godfray et al. 2010; INRA and CIRAD 2016; West et al. 2014). Aware that meat production is responsible for generating approx. $14.5 \%$ of total global greenhouse gas (GHG) emissions (see Gerber et al. 2013), the Intergovernmental Panel on Climate Change (IPCC) identified changing diets as a significant though undeveloped area for action (2014). A vegetarian diet could reduce emissions from food production by $55 \%$ per capita compared to the projected diet patterns in 2050 (Tilman and Clark 2014). Moreover, the significance of products from ruminants is worthy of note. Reducing ruminant meat and dairy products has the highest impact on GHG emissions compared to other foods (Gerber et al. 2013; Hedenus et al. 2014; Meier and Christen 2013). However, the question of how to achieve this change in dietary behaviour in the direction of reduced meat consumption as well as animal product consumption in general has yet to receive the attention it deserves (Dibb and Fitzpatrick 2014; Laestadius et al. 2013; Westhoek et al. 2011).

Regarding the problem of land use, two aspects need to be considered. First, there is the increasing need to grow feed crops to feed animals. According to published estimates, if the crops grown for animal feed and biofuel were instead directly consumed by humans, at a global level approximately $70 \%$ more calories would be available in the global food system (Pimentel and Pimentel 2003). As a result, four billion more people could be fed, which is more than the expected population growth of up to three billion people (Cassidy et al. 2013). Thus, the world's resources are being used in an extremely inefficient way when feed is converted into animal products (see also Garnett et al. 2015a). Yet $33 \%$ of the world's arable land is used to grow animal feed (FAO 2006). By adopting a vegetarian diet worldwide, the projected need for cropland in 2050 could be reduced by 600 million ha (Tilman and Clark 2014). Second, the large-scale extension of pastureland to feed ruminants at the expense of savannas or forests is highly problematic with regard to biodiversity loss. However, small-scale agriculture and extensive husbandry on pastures is generally less harmful or even beneficial for biodiversity (FAO 2006; Machovina et al. 2015). In total, $65 \%$ of the expansion in land use between 1960 and 2011 is due to increased production of animal products (Alexander et al. 2015).

Westhoek et al. (2011) estimate that animal husbandry accounts for roughly $30 \%$ of current global biodiversity loss, primarily as the result of changes in land use. To increase yields without further expansion of land use, high levels of fertilisers and pesticides are used (Cassman 1999; Tilman et al. 2002; Wirsenius et al. 2010). Between 2002 and 2012 the use of fertilisers (phosphate and nitrogen) rose by about $35 \%$ to more than 166 million tonnes per year (FAOSTAT 2015), resulting in considerable water and soil contamination (Pimentel 1996). Besides land use and pollution, climate change has a significant (mostly adverse) impact both on biodiversity and humans (Cramer et al. 2014). However, biodiversity is a critical condition for resilience (e.g. through infectious disease control) and the provision of key ecosystem services, such as wild harvest products. "It underpins much of modern agriculture as well as the livelihoods of many millions of people" (Sunderland 2011, p. 266; Thrupp 2000; Tscharntke et al. 2012). A further effect of increased land use due to high meat production and consumption is the threat of food security through land grabbing for the expansion of cropland for feed and pastures (Lovera 2015). Additionally, cheap meat exports to developing countries undermine the viability of local markets (FAO 2006; Godfray et al. 2010).

In this context, we ask whether it is realistic to reduce meat consumption, predominately in high-consumption areas such as the USA and Europe, in order to counter biodiversity loss and climate change. Indeed, positive developments with respect to meat reduction can be noted: about a billion people worldwide are already vegetarians or vegans, in part due to cultural and religious factors (Leahy et al. 2010). Germany currently has one of the highest proportions of vegetarians (11\%, eight million) and vegans $(1 \%, 870,000)$ in the Western world (YouGov 2014); roughly $9 \%$ of Austrians follow a vegetarian diet (IFES 2013), and in Israel approx. $13 \%$ deliberately avoid meat (Segal 2014), motivated primarily by health and ethical reasons (see, for example, Beardsworth and Keil 1991; Fox and Ward 2007). In fact, high levels of meat consumption considerably increase the risk of lifestyle diseases such as coronary heart disease and cancer (e.g. Rizzo et al. 2013; Joyce et al. 2012). Additionally, intensive husbandry raises serious concerns about animal welfare (Joy 2011).

In this paper, which focuses mainly on the barriers to reducing meat consumption, we also found some opportunities arising from these barriers. Moreover, we focus, for reasons of clarity, on meat production and consumption because their sustainability consequences and influencing factors are complicated enough without considering other animal foods such as dairy products and eggs. But concerns about human nutrition extend beyond the avoidance of meat products.

\section{Methods and theoretical framework}

We apply a meta-analysis that combines findings from various relevant studies on factors that influence meat consumption. There are many such studies, but a synthesis and systematic analysis of them is lacking. According to Magliocca et al. (2015) "meta studies [...] distil the findings of many narrowly focused analyses (i.e. "cases") to 
produce knowledge that is more generally applicable than may be derived from a single case" (p. 213).

We started by collecting together a bank of research studies. A type of snowball method was applied by tracking references. According to Greenhalgh and Peacock (2005), "in systematic reviews of complex and heterogeneous evidence [...] [as is the case for this paper] formal protocoldriven search strategies may fail to identify important evidence" (p. 1065). Using this method, we identified 71 relevant studies. Based on an initial assessment of the literature and the studies found via the snowball methodology, keywords were formulated to search for the literature on the ISI Web of Science. These included "pro-environmental", "consumer", "behaviour", "change", "resistance", "reasons", "determinants", "motives", "food", "choice", "diet", "animal", "product", "meat", "consumption", "sustainable", "vegetarian" and "vegan" in various combinations. Results were narrowed by the filter options on the ISI Web of Science. Temporal and geographical filters were not applied. However, the papers that were found are limited to the English language and to ones that were listed on the search engine. The search returned 440 publications, which were sorted according to the thematic fit of their titles and abstracts. The remaining 149 studies were further sorted according to their accessibility and by means of a full text review, resulting in the third database of 84 studies.

The following criteria were met:

- The content had to relate to meat or plant-based diets or at least to consumption behaviour

- The results of the studies had to provide more or less generalisable evidence about barriers to reducing meat consumption.

In total, 155 papers were selected for the meta-analysis (see Electronic Supplementary Material). Overlapping papers $(n=9)$ which were found twice (once using the snowball method and once using the search on the ISI Web of Science) were allocated to the papers found by the search using the ISI Web of Science (Fig. 1).

The next step of the analysis was to code the selected studies. Code families included method (review, qualitative, quantitative), data background (empirical primary data, empirical secondary data, theoretical), thematic category (meat-related, dietary behaviour, other behaviour), and the context of factors that influence meat consumption (personal, sociocultural and external factors, see below) with further sub-codes.

After reviewing a large number of other potential theoretical frameworks-based on Darnton's (2008) overview of behaviour change models-we adopted the model of pro-environmental behaviour developed by Kollmuss and Agyeman (2002) because of its comprehensiveness and its multifactor approach (see Fig. 2). According to Gifford and
Nilsson (2014), many studies have shown that well-known established social psychological models such as the theory of planned behaviour (Ajzen 1991), the value-belief-norm model (Stern 2000) and the norm activation theory (Schwartz 1977) should be "expanded to include other personal and social factors" (p. 141).

Our model here is divided into personal, sociocultural and external factors (such as political and economic factors). In order to select personal factors, we examined the influences of values/attitudes and knowledge/skills on potential behaviour. But we also looked carefully at the role of emotions and cognitive dissonance, which are core factors that potentially help us to understand personal reluctance to reduce or avoid meat consumption in relation to the associated meat paradox of loving animals but also eating and harming them (see below). The interrelations between emotions/cognitive dissonance and knowledge, values and attitudes are also explicitly incorporated into the model, which increases its complexity but also its explanatory power. In addition, we address the role of habits and taste in guiding meat consumption behaviour. The arrows in the model indicate how the different factors influence each other and, ultimately, meat-eating behaviour. While different internal and external incentives-explained in detail in the discussion section-would lead to reduced meat consumption, insufficient feedback on the consequences of meat-eating behaviour has to be understood as a barrier.

\section{Quantitative assessment of studies of the meta- analysis}

In most of the reviewed articles $(n=75)$, a quantitative research approach was employed, reflecting the representativeness of many results. Review articles $(n=54)$ were important for indicating synergies and the general applicability of theories and evidence. Due to the importance of both individual and cultural/social factors in influencing meat consumption, qualitative studies $(n=28)$ help to clarify complex behaviour patterns (Fig. 3a). More than $94 \%(n=145)$ of the studies present empirical data, of which the vast majority is primary data $(n=100)$. Nine articles are theoretical essays and were included both to reflect current discussions and to explain theoretical models (Fig. 3b). Nearly $60 \%$ of the reviewed studies cover aspects of meat consumption. A further $18.8 \%$ of the studies focus on dietary behaviour more generally, and the remaining fifth cover pro-environmental behaviour in general (Fig. 3c). Figure 3d shows the mean number of factors addressed per study. Meat-related studies address fewer factors than more general studies, showing the relevance of synthesis. In Fig. 3e it is evident that personal factors are analysed more often when addressing meat 
Fig. 1 Schematic depiction of the systematic review process (modelled on Biesbroek et al. 2013)

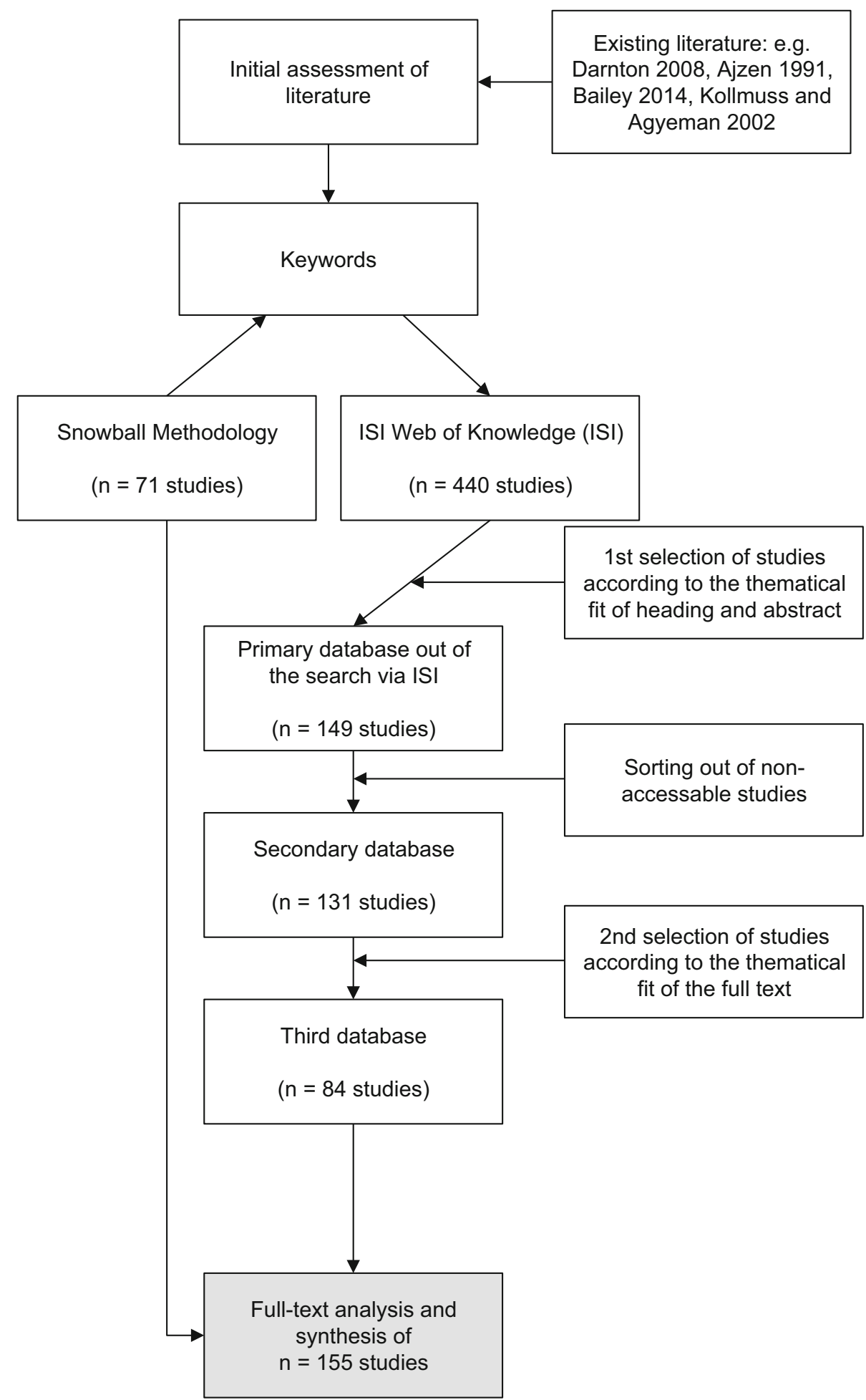

consumption or dietary and pro-environmental behaviour. Values and attitudes are named in 72 studies as relevant factors, while the second and third most cited factors are habits and taste ( $n=61$ studies) and knowledge and skills ( $n=57$ ), respectively. Emotions and cognitive dissonance are examined in 40 of the reviewed studies. Regarding the less-covered social and cultural factors, social roles and relationships are highlighted most often $(n=48)$, while culture and religion hardly appear at all. External factors relating to economic and political factors are named in 24 studies; the food environment (e.g. infrastructure) is named in 35 studies. This distribution is in line with our approach, which concentrates more on the internal/personal factors than on external factors as influences on meat consumption. 


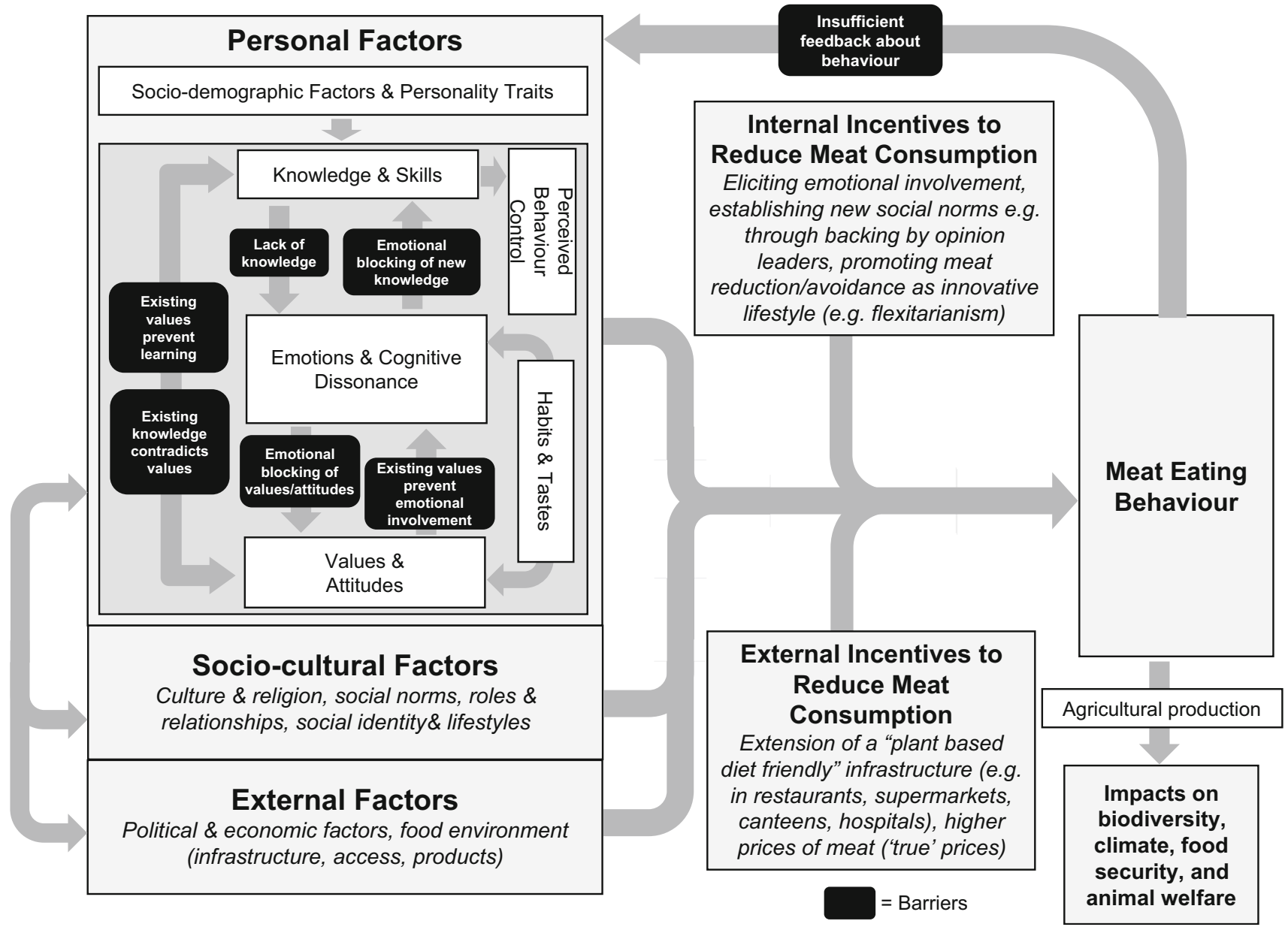

Fig. 2 Model of factors that influence meat-eating behaviour (based on the model of pro-environmental behaviour developed in Kollmuss and Agyeman 2002)

In Fig. 3d it also can be seen that "habits and taste" and "values and attitudes" are the main factors named in meatrelated studies, whereas "perceived behaviour control" is examined less than in studies that investigate other behaviour. This might suggest the importance of some factors but it may also provide an insight into what researchers regard as important factors to examine in regard to meat consumption. Most of the studies $(n=108)$ were published between 2008 and 2015, highlighting the emerging research field of meat consumption and its motives.

\section{Qualitative assessment: factors that influence meat-eating behaviour}

\section{Personal factors}

\section{Knowledge and skills}

Knowledge and skills are preconditions for determining behaviour. These include both factual knowledge (in the sense of knowledge of issues), and procedural knowledge (skills in the sense of knowledge of action strategies).

Knowledge of the environmental impacts of producing and consuming meat is low but increasing: $28 \%$ of people agree that livestock production has significant impacts on the environment. But when compared to other "food and sustainability" issues, this judgement is accorded lower significance than, say, choosing foods with less packaging (Garnett et al. 2015b; de Boer et al. 2013; Dibb and Fitzpatrick 2014; Lea and Worsley 2008, Tobler et al. 2011). In addition, Tobler et al. (2011) found that the more frequently people consumed meat, the less they perceived the environmental benefit of reducing meat consumption. An international survey by Chatham House found "a huge gap in public understanding of the role of meat and livestock in climate change. While $83 \%$ of respondents agreed that human activity is contributing to climate change, only $30 \%$ identified meat and livestock as a significant contributor" (Garnett et al. 2015b, p. 29).

Health concerns tend to rate higher than environmental or animal welfare concerns in motivating change in dietary 

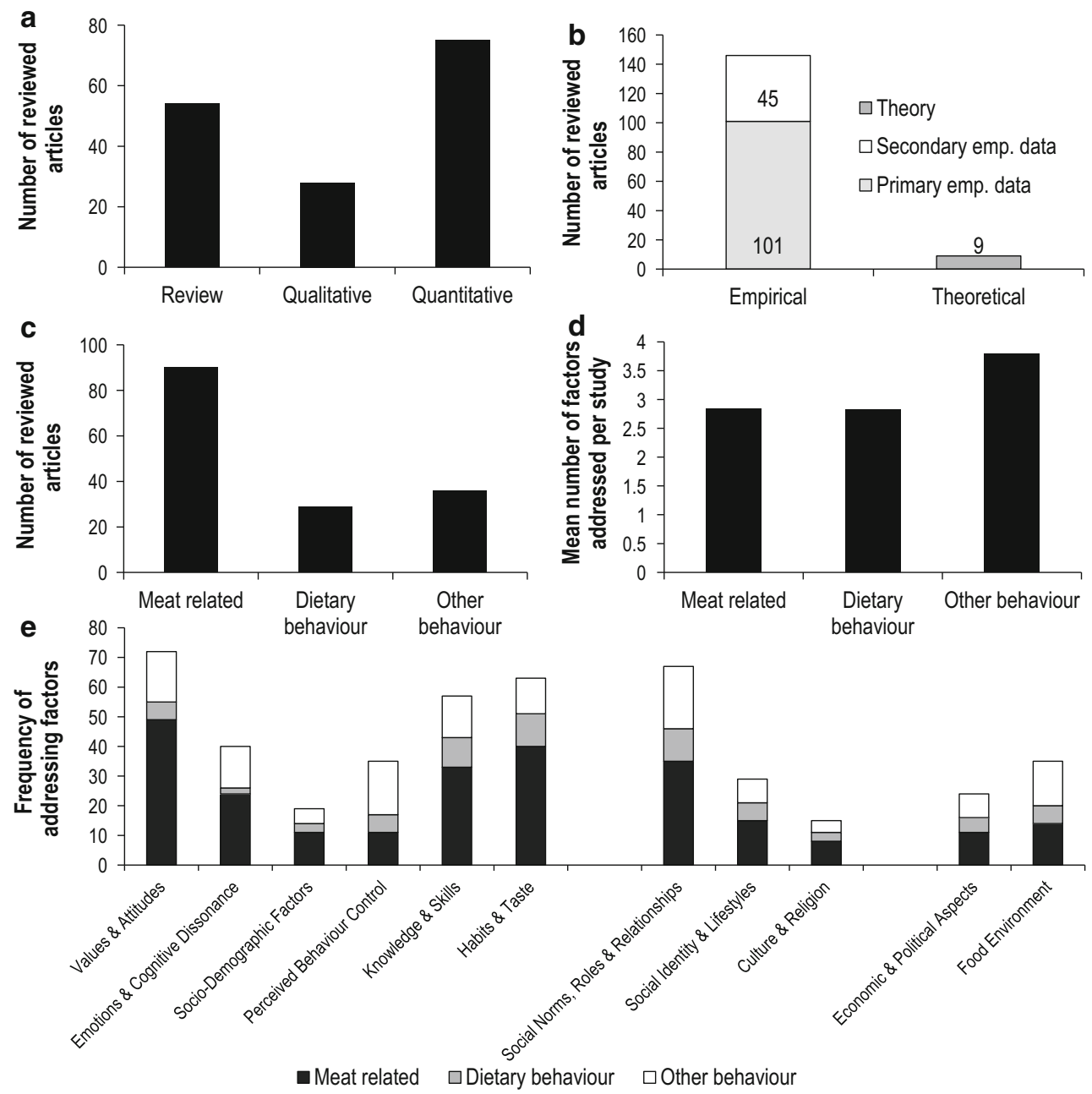

Fig. 3 a Total number of articles reviewed according to their approach. b Total number of articles reviewed according to their data background. c Number of studies reviewed according to the category of behaviour addressed. $\mathbf{d}$ Mean number of factors addressed per reviewed study. e Frequency of cited factors regarded as most

behaviour, though there are differences between sociodemographic groups (Cordts et al. 2013; Dibb and Fitzpatrick 2014; Richardson et al. 1993; Tobler et al. 2011; Wezemael et al. 2010). It is difficult to dispel the view that "meat is essential for maintaining health, and that vegetarian diets are nutritionally inadequate". This "lack of knowledge about the nutritional value of plant-based diets was a significant barrier to people reducing their meat consumption, particularly among middle aged people" (Dibb and Fitzpatrick 2014, p. 20; see also Barr and Chapman 2002). People still often think they eat more healthily than they actually do. While Dibb and Fitzpatrick (2014) feel that "the significance of strong public health messaging may be a valuable driver of reduced meat consumption" (p. 20), they are not confident that it will necessarily translate into changed dietary behaviour even if people understand the influential patterns of meat consumption, additionally divided according to the category of behaviour addressed in the respective study (one article can examine more than one category; right personal factors, middle sociocultural influences, left external factors). See text for full explanation

message regarding the value of meat-free or meat-reduced foods (see also Verbeke 2008).

With regard to the skills component, Dibb and Fitzpatrick (2014) quoted studies in which respondents admitted to a lack of knowledge of "meat-free" recipes, a lack of skills regarding how to use meat substitutes in their cooking, and a lack of cooking skills in general (see also Girod et al. 2014).

Ways of providing these kinds of skills and also increasing perceived behaviour control (see below) can include, for example, knowing how to cook tasty meat-free food or knowing where to obtain inexpensive, tasty meatfree food. The skills component is underestimated but should be taken very seriously. It is often "acquired through experience or observation, as much as through formal information" (Darnton and Evans 2013, p. 15). 


\section{Values and attitudes}

Values are the "guiding principles" that individuals use to judge situations: a person's sense of right and wrong or what "ought" to be; in contrast, attitudes are subjectspecific in that they refer to "a person's view or evaluation of another person, a physical object, an idea or action" (Darnton and Evans 2013, p. 7).

Meat-eating raises a whole range of value-based ethical questions related to the use of animals for food (for a good summarising discussion see Singer 1981, p. 120ff). Concerns such as avoiding the killing and/or suffering of animals (e.g. as a result of rearing, transportation and slaughtering practices) may lead to the voluntary avoidance of some or even all animal products in one's diet (e.g. Beardsworth and Bryman 2004; Beardsworth and Keil 1991; Dagevos and Voordouw 2013; Dibb and Fitzpatrick 2014; Graça et al. 2015; Santos and Booth 1996) and are increasingly integrated into the commercial food system (Beardsworth and Keil 1991). This has been confirmed by Mäkiniemi et al. (2011), who investigated differences between ethical and unethical food on the basis of their observation that there has been a substantial growth in ethical food consumption. The most positive moral attributes seem to be connected with vegetarian food (Deckers 2009). The respondents associated unethical food with, inter alia, meat, global mass production, global hunger, poor animal welfare and the suffering of animals.

The studies analysed in our meta-analysis clearly confirm that the dominant motivational factors for being vegetarian are moral values, in particular those concerning animal welfare (Bastian et al. 2012; Bobic et al. 2012; Beardsworth and Keil 1991; Lindeman and Väänänen 2000). Rothgerber (2014a) surveyed "semi-vegetarians" and vegetarians and found that "semi-vegetarians" see humans as being less similar to animals and express a lower level of expressed "disgust" towards meat than vegetarians do. By surveying 945 adults, Fessler et al. (2003) found that "moral vegetarianism conforms to traditional explanations of moral reasoning" (p. 31).

Gifford and Nilsson (2014) summarise several studies which show that values have to be considered in terms of orientations towards self and others, "with individuals with cooperative (pro-social) orientations emphasizing joint gains between self and other, whereas those with competitive and individualistic orientations (pro-self) emphasize gains to themselves" (p. 144). As the outcome of high meat consumption is not only harmful for animals but also for other people (e.g. in the context of food insecurity) and the environment (destroying biodiversity) this distinction is also important in the context of this article because "individuals who are more people oriented and less authoritarian have higher levels of moral development, and believe their actions will make a difference" (p. 144).

\section{Emotions and cognitive dissonance}

Darnton and Evans (2013, p. 13) define emotions as "how people feel about something"; hence, they are an aspect of behavioural decision-making. Emotions are often underestimated in models of behaviour change, as for example in some models and studies in which they are grouped under attitudes. Exceptions include Triandis' (1977) theory of interpersonal behaviour and the risk as feelings model in the study by Loewenstein et al. (2001).

Emotional involvement can be understood as the ability to have an emotional reaction when confronted with animal suffering (Ericson et al. 2014; Filippi et al. 2010). One could conclude that "the stronger a person's emotional reaction, the more likely that person will engage in a new behaviour" (Kollmuss and Agyeman 2002, p. 254). Therefore, better inclusion of "more emotional and feeling elements in food choice rather than simply addressing the rational cognitive issues prevalent in literature" (Shepherd 2001, p. 129) is necessary.

Our analysis of several studies on meat consumption shows that a mechanism called cognitive dissonance acts as a barrier to feeling emotionally involved and thus to changing meat-eating behaviour (Bastian et al. 2012; Bergmann et al. 2010; Beardsworth and Bryman 2004; Joy 2005; Loughnan et al. 2010, 2014; Piazza et al. 2015).

Cognitive dissonance is a theory developed by Festinger (1957) in order to understand human behaviour and more specifically human emotions (Allen 2015). A significant number of studies devoted to explaining meat-eating behaviour have placed a strong focus on this theory (Bergmann et al. 2010; Loughnan et al. 2014; Joy 2011). Following Kollmuss and Agyeman (2002) we included Festinger's theory in our model. The literature that we reviewed confirms this "meat paradox" (see also Loughnan et al. 2014) which meat-eaters experience when they are reminded that their behaviour may not match their values and attitudes, and the resolution of this tension by changing diet fits with this dissonance (Bastian et al. 2012; Bergmann et al. 2010; Harmon-Jones and Mills 1999; Piazza et al. 2015). However, people tend to avoid or resist information about the negative consequences of meat-eating because they contradict or threaten basic perspectives on fairness and ethical behaviour and can give rise to strong, emotionally distressing reactions. Psychological responses aimed at relieving people of these negative feelings include denial and delegation as a means of removing feelings of guilt (e.g. Antonetti and Maklan 2014; Bastian et al. 2012; Bergmann et al. 2010; Kaiser and 
Shimoda 1999; Kollmuss and Agyeman 2002; Joy 2005). The person who delegates refuses to accept personal responsibility and blames others (e.g. food industries, multinationals and the political establishment), as is the case with respect to meat consumption in relation to climate change (de Boer et al. 2013). People who delegate or deny are unlikely to change their behaviour towards meat reduction or avoidance (Bergmann et al. 2010).

\section{Habits and taste}

The consumption, purchase and preparation of meat is determined by the habits and unconscious routines of dayto-day practices. Habits tend to be repetitive, routine, reliable, reinforcing and rewarding (Lewin 1951; O'Riordan and Stoll-Kleemann 2015). Graça et al. (2015) analysed over 400 open-ended responses to meat-eating. They found that respondents cluster broadly into three key groups: those with a strong attachment to meat and an unwillingness to change behaviour, those with no strong feelings and a willingness to change habits and those who have morally internalised a strong disgust towards meat.

Several authors found that habits and routines are among the main barriers to reduced meat consumption (Lea et al. 2006; Dagevos and Voordouw 2013; Graça et al. 2015). Dibb and Fitzpatrick (2014) add that many of our day-today food habits are routine in that we eat often and without much deliberation. The trend towards "convenience" has been a major influence on food purchasing habits, encouraged by a lack of time, skills or interest in cooking. This demonstrates how behaviours are facilitated by the structures of the production and supply system, but also by social and cultural assumptions and expectations (see below).

Taste is often mentioned as an important reason either for eating or for avoiding meat (Beardsworth and Bryman 2004; Dibb and Fitzpatrick 2014; Piazza et al. 2015; Tucker 2014; Wiig and Smith 2008). Vegetarians and vegans often feel disgust towards eating meat (Graça et al. 2015). Taste preferences change over the course of a person's life, and the range of taste acceptability is of varying magnitudes in different circumstances (Furst et al. 1996). It varies widely among individuals and cultures. Shepherd (2001) emphasises that taste as a sensory perception within food choice in general is only one reason among other possibly more important factors such as self-identity and moral obligation.

\section{Sociodemographic factors and personality traits}

Lifestyle choices regarding food are associated with socioeconomic variables such as social class (higher educational level and/or higher economic status) and living in more urban areas (Bobic et al. 2012; Gifford and Nilsson 2014; Garnett et al. 2015b). Regarding meat-eating behaviour specifically, the most influential sociodemographic factors are gender, age and socioeconomic status (Lea and Worsley 2001; Stoll-Kleemann 2014; Cordts et al. 2013).

Tobler et al. (2011) found that gender was the strongest predictor of levels of meat consumption. Women are more emotionally engaged, show more concern about environmental destruction and animal welfare, have less faith in technological solutions and are more willing to change (Kollmuss and Agyeman 2002). Men tend to eat more meat and are less willing to consider reducing their consumption (Cordts et al. 2013; Dibb and Fitzpatrick 2014). Young people appear more open to "flexitarian" eating with the highest proportion of non-meat eaters, potentially indicative of a generational shift in attitudes and behaviours towards meat-eating (Dibb and Fitzpatrick 2014). There are significant differences across generations as to why people choose a vegetarian diet and associated lifestyles: younger vegetarians are swayed more by the moral and environmental reasons to be vegetarian, while people aged 41-60 are prompted by health reasons (Pribis et al. 2010). In this context, family history and childhood experience play a role in that the foods one eats in childhood are also preferred adult choices. In addition, by early adulthood, individuals have adopted a culturally based set of beliefs and attitudes concerning the edibility of objects (Rozin 1984 in Haverstock and Forgays 2012).

Darmon and Drewnowski (2008) found that people of lower socioeconomic status (education, income and/or occupation) and more limited economic means follow less healthy diets, including larger quantities of fatty meats. For low-income groups in the USA, meat was the most important food and the one to which they allocated the largest portion of their food budget, up to $50 \%$ more compared to higher income households. High meat consumption can no longer be seen as an indicator of prosperity. People with a higher level of education prefer a vegetarian diet (see also Cordts et al. 2013; Wiig and Smith 2008). This is confirmed at a global level by Leahy et al. (2010) who revealed that vegetarianism slightly increases with income. Yet in emerging economies, such as in China, meat consumption is associated with displaying new levels of wealth (Garnett and Wilkes 2014).

In addition, we know that the "Big Five" personality traits (Costa and McCrae 1992) —openness to experience, conscientiousness, extraversion, agreeableness and emotional stability-influence why and what we eat (Keller and Siegrist 2015; Goldberg and Stryker 2002). In this context, conscientiousness is the most important personality trait because a lack of it leads to impulsive eating and a loss of self-control in the face of tempting food situations. Extraversion was also found to be linked to unhealthy 
eating habits due to external factors like the smell or taste of food (Keller and Siegrist 2015). With respect to environmental concern, Gifford and Nilsson (2014) found that conscientiousness, and in addition openness and agreeableness, were strongly linked to environmental engagement (see also Ericson et al. 2014). Whether these findings are fully transferable to meat-eating behaviour needs further investigation.

\section{Perceived behaviour control}

In psychological models, perceived behaviour control, also called locus of control, is a determinant of behaviour. Its importance for pro-environmental behaviour has been shown in several studies, as summarised by Antonetti and Maklan (2014) and Gifford and Nilsson (2014). According to Ajzen (1991) perceived behaviour control is defined as the "perceived ease or difficulty of performing the behavior" (p. 188). People who feel they have the selfefficacy to carry out a certain behaviour are more likely to do so than people who perceive themselves as lacking the ability to behave in the desired way.

Wyker and Davison (2010) asked people about their perceived personal control if they imagined following a plant-based diet for the next year and to what extent they felt capable of doing so. The results indicate that people who are already close to adopting a plant-based diet perceive a stronger sense of control compared to people who are in the phase prior to contemplating switching. This finding is supported by Mäkiniemi and Vainio (2014), who found that vegetarians regarded barriers such as high prices, poor supply of alternative foods, and lack of knowledge as being less relevant than non-vegetarians did. In this respect, perceived behaviour control is interrelated with the factor "food environment" of the proposed model. The notion of perceived behaviour control may also be a matter of consumer sovereignty and environmental responsibility (Peattie 2010; Barker et al. 2009; Ericson et al. 2014; Girod et al. 2014; Fischer and Barth 2014). According to Rothgerber (2014a), reducing the perceived choice to eat meat is also a coping strategy to overcome cognitive dissonance.

\section{Sociocultural factors}

Cultural and religious traditions, social norms, roles and relationships and the construction of identities and lifestyles influence and shape people's behaviour towards meat.

\section{Culture and religion}

"Meat holds cultural importance for many people as an essential part of a meal. Such motivation is seen as driven by the powerful forms of symbolism which are attached to meat in many cultures" (Beardsworth and Bryman 2004, p. 314). Fiddes (1992) suggests that in Western thought and practice, the consumption of red meat is driven by the desire to express human power in order to dominate the natural world. On the other hand, in many cultures and religions "the consumption of various types of meat is hedged around with complex sets of taboos and prohibitions" (Beardsworth and Bryman 2004, p. 314). Haverstock and Forgays (2012) confirm that animal product shifters see such eating patterns as a part of their cultural and religious backgrounds, which may dictate some food choices or avoidance since the ahimsa concept (non-injury to living creatures) is a basic tenet of religions such as Buddhism, Hinduism and Jainism.

Joy (2011) confirms that a majority of meat-eaters view eating animals as a cultural norm rather than a choice because it is "not a necessity for survival": people typically "don't think about why they find eating dogs disgusting and eating cows appetizing or vice versa, or why they eat any animals at all" (p. 105; see also Piazza et al. 2015; Rauschmayer and Omann 2012). Higgs (2015) explains that people follow these kinds of eating norms because doing so "enhances affiliation with a social group and being liked" and apparently confirms that one is behaving correctly.

Nath (2010) has unearthed a belief according to which meat provides strength and vigour to men, a key reason why vegetarianism is not an appealing choice. In addition, for men, the number of vegetarian and non-vegetarian friends is the most influential predictor for the frequency of meat consumption (Lea and Worsley 2001) because stereotypes about masculinity are therefore expressed and fulfilled (Vartanian 2015; Ruby and Heine 2011). This is confirmed by two studies conducted by Ruby and Heine (2011) which showed that male vegetarians were perceived as less masculine than meat-consuming men but enjoy a much stronger sense of virtue and morality. Schösler et al. (2015) concluded that a combination of traditional framings of masculinity and a Western food environment where meat is both abundant and cheap impedes a transition to a diet based less upon meat.

\section{Social norms, roles and relationships}

The presence of other people at an eating occasion or when choices are made about food "has a powerful effect on behaviour [...] because people have a highly developed capacity to learn from the behaviour of others and find the approval of others rewarding and disapproval aversive" (Higgs 2015, p. 38; Cialdini et al. 1990). This dietary behaviour, which is related to perceptions of normative behaviour by socially connected peers, can be a barrier as well as an opportunity (e.g. Verain et al. 2015). While Wyker and Davison (2010) found that "normative beliefs 
regarding how much friends, family, and other colleagues believed the participant should follow a plant-based diet [...] [are] strong predictors of intentions to do so" (p. 175), Salonen and Helne (2012) focus more on social group thought and behaviour as central obstacles to shifting towards a vegetarian diet. Social norms may be communicated directly via cultural practices in a given situation (Higgs 2015).

\section{Social identity and lifestyles}

Food consumption is viewed as a social marker to construct social identities and lifestyles (Sneijder and te Molder 2009; Shepherd 2001). Identity is determined primarily by lifestyle or people's actual practices, although consumers' sociodemographic characteristics may still play a role. Food consumption in general or meat avoidance in particular can be regarded as a choice that is part of the lifestyle decisions people make in late modernity (Grunert et al. 2001).

In this context it is also of interest that people "adjust their eating behaviour to manage their public image and create a certain impression on others" (Higgs 2015, p. 39). The already mentioned increase in the number of people who call themselves "flexitarians" could be interpreted in this context as a new food style which provides a satisfying identity and lifestyle (Verain et al. 2015). Flexitarians follow vegetarian consumption patterns but occasionally include meat products and have a broader interpretation of reduced meat consumption without avoiding meat altogether (ibid.), e.g. when suitable vegetarian food options are temporarily unavailable or in cases where they want to "avoid embarrassment in certain social settings" (Beardsworth and Keil 1991, p. 20). Although this definition places flexitarianism on a spectrum between a meat-centred diet and vegetarianism, flexitarians are seen as being much more similar to meat-eaters than to vegetarians (Janda and Trocchia 2001) because they have a greater liking for meat, are less disgusted by it and show less emotional resistance to meat consumption compared to vegetarians. However, they exhibit more feelings of guilt compared to meat-eaters (Rothgerber 2014b).

\section{External factors}

Here we address factors that influence diet that go beyond the personal and sociocultural level. These include political and economic dimensions as well as the overall food environment.

\section{Political and economic factors}

Behaviour change in the direction of meat reduction or avoidance requires an inclusive approach that goes beyond persuading or "nudging" individuals to change dietary patterns. It requires supportive government policies and practices, new and different business practices and civil society initiatives working in synergy (Dibb and Fitzpatrick 2014; Biesbroek et al. 2013; Darnton and Evans 2013; Garnett et al. 2015b; Thøgerson 2014; Westhoek et al. 2011). While several authors still claim that "advocating for reduced meat consumption as part of healthy sustainable diets has not yet translated into policies and practices from government to support consumer behaviour change" (Dibb and Fitzpatrick 2014, p. 5; Dagevos and Voordouw 2013; Laestadius et al. 2014; Bailey et al. 2014; Westhoek et al. 2011), it is evident that a variety of institutions have already started to take action and/or are preparing to do so. This includes governments in countries such as China, where the government is running a major campaign employing well-known U.S. actors such as Arnold Schwarzenegger (The Guardian 2016), and Germany, where reducing meat consumption is now included in the climate goals (BMUB 2016). It also includes private companies such as IKEA, which is promoting vegan food in its restaurants (IKEA Group 2015), and local, national and global NGOs and private foundations such as WWF (2014).

One reason for the previous and present political inaction is the fear that attempts to reduce meat consumption would likely mobilise protest from powerful interest groups (WBGU 2011; Withana et al. 2012). Joy (2011, p. 38) calculates that in the USA "animal agribusinesses is a $\$ 125$ billion industry controlled by a handful of corporations, which include agro-chemical and seed companies [...] processing companies [...]; food manufacturers [...]; food retailers $[\ldots]$; transportation systems, [...] [and producers of] pharmaceuticals [and] farm equipment". Sexton (2013) has revealed that these power relationships in the U.S. agricultural markets favour consolidation and contract buying so that free markets are no longer relevant in the food sector.

One highly problematic factor is the level of subsidies across the world, which leads to market distortions and misallocations (Withana et al. 2012). The subsidies for livestock-based products such as animal feed and animal products provided by industrialised countries (OECD members) amount to $\$ 52$ billion (Heinrich-Böll-Foundation 2014). In many countries, meat is subject to a reduced level of VAT (Keller and Kretschmer 2012).

Monetary considerations strongly influence people's food choices, including meat consumption behaviour (Furst et al. 1996; Ritson and Petrovici 2001; Lanfranco and Rava 2014; Edjabou and Smed 2013). Where meat is cheap, price-as a primary consideration for food shoppers-becomes a barrier for reducing meat consumption. This is the case, for example, in Germany, where subsidies and 
industrial factory farming result in artificially low prices. In contrast, in some other countries meat is one of the most expensive food items in people's shopping baskets, so that eating less meat makes it possible to save money and potentially trade up to better-quality meat (Dibb and Fitzpatrick 2014). Rao et al. (2013) and Jones et al. (2014) stress that these relationships are too convoluted and underresearched for definitive conclusions to be drawn but should not be disregarded.

\section{Food environment: infrastructure, access, products}

The food environment encompasses the physical surroundings and social climate of meat-eating or avoidance, including specific food supply factors in the environment such as types of food, food sources, and availability of and access to foods (Dagevos and Voordouw 2013; Verain et al. 2015; Furst et al. 1996). Whereas supermarkets and grocery stores may cluster in more affluent neighbourhoods, some lower-income neighbourhoods have been characterised as "food-deserts" (Darmon and Drewnowski 2008).

Interest in non-meat sources of protein is increasing. A number of meat replacement or meat alternative products have grown in popularity in recent years and provide opportunities to help consumers shift to a lower meat diet (Schösler et al. 2012). Many new products have been developed which add to the classic plant-based diet such as legumes, tofu, seitan and products based on lupines.

The food environment is growing larger thanks to a steadily expanding range of tasty and affordable vegetarian and vegan products in supermarkets and on the menus of restaurants, canteens and college refectories (Lea et al. 2006). The food companies and the food service sector already provide non- or lower meat convenience meal alternatives in order to target convenience and eating out markets. Overall, the increase in infrastructure that supports a plant-based diet could make an important opportunity to reducing meat consumption.

\section{Discussion: turning barriers into opportunities for reduced meat consumption}

In this section, we discuss how the above-mentioned factors, which are mainly barriers, can be turned into opportunities for reducing meat consumption. Because of limited space, we do not discuss each factor separately (see Table 1 for a brief overview) but emphasise strategies which encourage synergetic effects among these factors. A common feature of all the approaches discussed below is that sociodemographic and group-specific factors such as gender, age, and socioeconomic status should be regarded as cross-sectional because meat-eating behaviour is strongly influenced by them.

One example would be to develop "positive" messages that explicitly connect the issues of dietary flexibility, animal health and personal health, while framing specific benefits for different target groups (e.g. health benefits for the elderly and men or ecological benefits and generational legacy for young people (Joyce et al. 2012; Dibb and Fitzpatrick 2014; Garnett et al. 2015b). Another would be to focus more on experience and observation in learning processes so as to reach people with lower levels of education (Darnton and Evans 2013).

Appropriate knowledge, values and attitudes are necessary conditions, but in themselves are not sufficient to foster changes in dietary behaviour (Verbeke 2008; Dibb and Fitzpatrick 2014). In this respect, emotions have a stronger influence on behavioural changes (Kollmuss and Agyeman 2002; Allen 2015; Piazza et al. 2015). Although, consequently, ways to promote plant-based diets might include the provision of information about, e.g. the nutritional adequacy and preparation of plant-based meals, and wider-ranging knowledge of alternatives to meat, it makes no sense to "merely make rational appeals to people to change behaviour based on factual and logical arguments" (Darnton and Evans 2013, p. 13). Instead, it appears more useful to "provide emotional and empathetic messaging" (ibid., p. 13).

In order to successfully create or activate knowledge/ skills and values/attitudes that promote reduced meat consumption, cognitive dissonance needs to be overcome, since it is a key determinant of meat consumption behaviour-with associated denial and defence strategies. As described above, meat-eaters tend to avoid or resist information about the negative consequences of meat-eating in order to overcome strong, emotionally distressing reactions. Social and cultural norms are "potent and pervasive" and as such are strong and closely interrelated barriers since they function as an excuse for or even legitimisation of meat-eating behaviour, while at the same time helping to intimidate people who depart from this accepted behaviour and fear social disapproval (e.g. Higgs 2015, p. 42).

Therefore, cognitive dissonance may be lessened by the promotion of new social norms, e.g. by encouraging people to move in widening social circles that have fresh attitudes about food and personal integrity (O'Riordan and StollKleemann 2015). This can be achieved by means of different strategies. One is to stress the role of vegan or vegetarian opinion leaders as role models for those who feel insecure about their decision to avoid meat and other animal products or feel under social pressure not to change their dietary habits. Many prominent role models are taking a lead (ibid.). Actors, singers, TV presenters, politicians and sportspeople such as Paul McCartney, Bill Clinton, 
Table 1 Table summarising barriers to and opportunities for reducing meat consumption

\begin{tabular}{|c|c|c|}
\hline Factors & Barriers & Opportunities \\
\hline Knowledge and skills & $\begin{array}{l}\text { Low knowledge of the consequences of high meat consumption } \\
\text { and reasons for reduced meat-eating behaviour; } \\
\text { Lack of skills relating to practical issues (such as those related to } \\
\text { vegetarian cooking); } \\
\text { Denial mechanisms provided by cognitive dissonance, which } \\
\text { block new knowledge }\end{array}$ & $\begin{array}{l}\text { Campaigns based on emotional messages, specific } \\
\text { arguments and with particular tools for targeted } \\
\text { groups; } \\
\text { Increasing skills that facilitate a plant-based diet; } \\
\text { Mechanisms and tools to overcome cognitive } \\
\text { dissonance (see below) }\end{array}$ \\
\hline Values and attitudes & $\begin{array}{l}\text { Low priority of values/attitudes which favour low meat } \\
\text { consumption; } \\
\text { Denial mechanisms provided by cognitive dissonance and social } \\
\text { norms which block the incorporation of ethical food attitudes } \\
\text { into behaviour }\end{array}$ & $\begin{array}{l}\text { Campaigns based on emotional and symbolic } \\
\text { messages; } \\
\text { Mechanisms and tools to overcome cognitive } \\
\text { dissonance (see below) }\end{array}$ \\
\hline $\begin{array}{l}\text { Emotions and } \\
\text { cognitive dissonance }\end{array}$ & $\begin{array}{l}\text { Cognitive dissonance blocks new knowledge and adequate } \\
\text { values through denial and defence mechanisms }\end{array}$ & $\begin{array}{l}\text { Emotional and symbolic messaging, promotion of } \\
\text { new social norms (see below) } \\
\text { Removing cognitive dissonance by changing } \\
\text { behaviour to encourage reduced meat } \\
\text { consumption }\end{array}$ \\
\hline Habits and taste & $\begin{array}{l}\text { Day-to-day food habits as unconscious routine; } \\
\text { Taste preferences towards meat; } \\
\text { The production and supply system has a major influence on food } \\
\text { habits }\end{array}$ & $\begin{array}{l}\text { Infrastructure supportive of plant-based diet: } \\
\text { vegetarian-friendly shopping and dining } \\
\text { environments (including canteens and hospitals) } \\
\text { support the establishment of new habits }\end{array}$ \\
\hline $\begin{array}{l}\text { Sociodemographic } \\
\text { variables and } \\
\text { personality traits }\end{array}$ & $\begin{array}{l}\text { Being male, elderly, belonging to a lower social class (in terms } \\
\text { of income and/or education); } \\
\text { Personality traits: being extravert, facing a lack of } \\
\text { conscientiousness }\end{array}$ & $\begin{array}{l}\text { Strong health argument for men and the elderly; } \\
\text { Promoting flexitarianism as a new food style }\end{array}$ \\
\hline $\begin{array}{l}\text { Perceived behaviour } \\
\text { control }\end{array}$ & $\begin{array}{l}\text { Low perceived ability to control behaviour reduces the } \\
\text { probability of behaving in the desired way }\end{array}$ & $\begin{array}{l}\text { Increasing skills and self-esteem by stressing the } \\
\text { role of vegan/vegetarian opinion leaders as role } \\
\text { models }\end{array}$ \\
\hline Culture and religion & $\begin{array}{l}\text { Symbolism attached to meat: desire to express human power in } \\
\text { order to dominate the natural world; } \\
\text { Cultural belief that meat provides strength and vigour (in } \\
\text { particular to men) }\end{array}$ & $\begin{array}{l}\text { Taboos and prohibitions in several religions (e.g. the } \\
\text { ahimsa concept); } \\
\text { Promotion of new social and cultural norms (see } \\
\text { below) }\end{array}$ \\
\hline $\begin{array}{l}\text { Social identity and } \\
\text { lifestyles }\end{array}$ & $\begin{array}{l}\text { Meat consumption as a social marker in the construction of } \\
\text { social identities and lifestyles (e.g. as a sign of prosperity or } \\
\text { masculinity) }\end{array}$ & $\begin{array}{l}\text { Flexitarianism as a new food style; } \\
\text { Enhancing social status of plant-based diets }\end{array}$ \\
\hline $\begin{array}{l}\text { Social norms, roles } \\
\text { and relationships }\end{array}$ & $\begin{array}{l}\text { Perceptions of normative behaviour by socially connected peers } \\
\text { who favour meat consumption }\end{array}$ & $\begin{array}{l}\text { Promotion of new social norms, e.g. by stressing the } \\
\text { role of vegan or vegetarian opinion leaders as role } \\
\text { models and community-based social marketing }\end{array}$ \\
\hline $\begin{array}{l}\text { Political and } \\
\text { economic factors }\end{array}$ & $\begin{array}{l}\text { Lack of political will; } \\
\text { Powerful lobbies in agro-industry; } \\
\text { High subsidies for the production of animal-based food; } \\
\text { Low prices of animal-based products }\end{array}$ & $\begin{array}{l}\text { Increasing prices (e.g. by eliminating harmful } \\
\text { subsidies, internalising external costs and/or } \\
\text { imposing taxes on animal production and } \\
\text { products) }\end{array}$ \\
\hline Food environment & $\begin{array}{l}\text { No broad infrastructure that facilitates a plant-based diet; lack of } \\
\text { vegetarian-friendly shopping and dining environments } \\
\text { (including canteens, college refectories and hospitals), } \\
\text { especially in rural areas }\end{array}$ & $\begin{array}{l}\text { Increase in tasty and affordable vegetarian products } \\
\text { in supermarkets, on the menus of restaurants, in } \\
\text { hospitals, canteens and college refectories }\end{array}$ \\
\hline
\end{tabular}

Mike Tyson, Ben Stiller, Michelle Pfeiffer, Demi Moore, Johnny Depp and Kate Winslet are constantly making their views on meat consumption publicly known (Dibb and Fitzpatrick 2014). These role models could be a way to enable participants to feel pride and personal esteem in "doing the sustainably right thing" even when others around them are not doing the same. This could help to neutralise the powerful effect of social pressure exerted by meat-eaters during meals.

Additional approaches to support this process can be facilitated by techniques used in community-based social marketing. This is based on the idea that "norms, commitment and social diffusion have at their core the interactions of individuals in a community and aim at 
developing supportive social interaction" (McKenzieMohr and Smith 1999, p. 97). Similarly, Noppers et al. (2014) found that "the more people think that adopting a sustainable innovation has positive outcomes for their selfidentity and social status, the more likely they are to adopt sustainable innovations" (p. 60). Because a lot of people see flexitarian, vegetarian, or even vegan lifestyles as a sustainable innovation (see above) this seems to be a very promising approach. The authors recommend that "targeting symbolic attributes might need subtle and indirect methods as well" and lessons that "can possibly be drawn from promotion strategies of high-status and innovative brands" (ibid., p. 61).

If cultural and social norms shift, so do the external settings that influence diet. It is easier to eat differently if there are an increasing number of high-quality vegetarian restaurants or vegan outlets nearby. If it were the "norm" to link meatless foods to personal health, animal welfare and sustainability issues, then habits could be readjusted and gradually form a "new conformity". Loyalty and conformity to social reference groups and role models help to determine values, interpretations and emotions. If the core beliefs of the reference group shift and its dominant behaviour is opened up to refreshing reinterpretations, then "new habituations" can develop (O'Riordan and StollKleemann 2015).

Finally, various reformist political and economic measures should also be mentioned. These include removing harmful subsidies from livestock production, imposing taxes, and more generally internalising social and environmental externalities in food production costs (StollKleemann 2014; Stoll-Kleemann and O'Riordan 2015; Keller and Kretschmer 2012).

Concerning the question of who will implement and pay for the measures to reduce meat consumption that have been discussed and then summarised in Table 1, a variety of institutions such as the Chinese government, companies like IKEA and NGOs like WWF have already started to take action as noted above.

\section{Conclusions}

Shifting diets to reduce high levels of meat consumption in developed and transition countries is a key leverage point for tackling biodiversity loss and climate change (Gerber et al. 2013; Joyce et al. 2012; IPCC 2014; Tilman and Clark 2014), e.g. globally about $30 \%$ of current biodiversity loss and $14.5 \%$ of greenhouse gases are due to animal husbandry (Gerber et al. 2013; Westhoek et al. 2011). However, government policies supporting reduced meat consumption are only slowly translating into practice that promotes consumer behaviour change (Dibb and
Fitzpatrick 2014). On the other hand, the very high level of subsidies across the world, which leads to market distortions and misallocations, is counterproductive, since, for example, it leads to artificially low prices and thus stimulates consumption. Political action is urgently required to address this problem. As a parallel strategy, several studies (e.g. de Bakker and Dagevos 2012; Dagevos and de Bakker 2015) show that one very efficient route towards change is to focus on consumers as change agents for reduced meat consumption, with abilities and inclinations that need to be strengthened.

We based our review of barriers, opportunities and steps that need to be taken in order to encourage the consumption of less meat on a meta-analysis of 155 studies so as to combine findings from various relevant studies. There are many such studies, but a synthesis and systematic analysis of them is lacking. We identified 11 influence factors for a stubbornly high level of meat consumption in developed countries. "Values and attitudes" (73) and "social norms, roles and relationships" (65) are mentioned most often. However, this does not mean that these factors are more important than, e.g. "emotions and cognitive dissonance", the "food environment" or other personal, social and external factors, but it may provide an insight into what researchers regard as important factors to examine with regard to meat consumption. This might be because the "food system" and its value chain also consist of the people working for it and therefore influencing and creating it. These people are also affected by individual factors found in our analysis such as cognitive dissonance, etc. In our qualitative assessment, the most relevant influences on behaviour appear to be emotions and cognitive dissonance and, again, sociocultural factors (as a whole) influenced by economic factors and the food environment. Sociocultural factors are important because meat still has an important social status for many people as an essential part of a meal and its consumption or avoidance can be regarded as a choice that is part of the lifestyle decisions people make in late modernity. Opportunities and strategies need to be tailored in a target group-specific manner and approaches such as consumer segmentation should be considered. They can also address several different influence factors at once to produce synergy effects. For example, the promotion of new social and cultural norms by means of stressing the role of vegan or vegetarian opinion leaders as role models as well as community-based social marketing or emotional and symbolic messaging addresses factors such as cognitive dissonance, all sociocultural-related factors and perceived behavioural control alongside influences on the political and economic context. A variety of institutions have already started to do this: from governments in countries such as China, where the government is running a major campaign employing well-known U.S. actors such as 
Arnold Schwarzenegger, to companies such as IKEA, which is promoting vegan food, to local, national and global NGOs and private foundations such as WWF.

Although we are beginning to understand the motives behind meat consumption, further interdisciplinary and integrative research is necessary to learn more about the interconnectedness of factors and the appropriate strategies that it entails. Moreover, the influence of political and economic factors and the food environment needs to be researched in much greater depth and breadth.

Open Access This article is distributed under the terms of the Creative Commons Attribution 4.0 International License (http://crea tivecommons.org/licenses/by/4.0/), which permits unrestricted use, distribution, and reproduction in any medium, provided you give appropriate credit to the original author(s) and the source, provide a link to the Creative Commons license, and indicate if changes were made.

\section{References}

Ajzen I (1991) The theory of planned behaviour. Organ Behav Hum Decis Process 50:179-211. doi:10.1016/0749-5978(91)90020-T

Alexander P, Rounsevell MDA, Dislich C, Dodson JR, Engström K, Moran D (2015) Drivers for global agricultural land use change: the nexus of diet, population, yield and bioenergy. Global Environ Change 35:138-147. doi:10.1016/j.gloenvcha.2015.08. 011

Allen K (2015) Emotions \& Cognitive Dissonance: Your supreme divine guidance. Collective Evolution (CE). http://www.collec tive-evolution.com/2013/02/05/emotions-and-cognitive-disso nance-theory-your-supreme-divine-guidance/. Accessed 9 June 2015

Antonetti P, Maklan S (2014) Feelings that make a difference: how guilt and pride convince consumers of the effectiveness of sustainable consumption choices. J Bus Ethics 124:117-134. doi:10.1007/s10551-013-1841-9

Avellan T, Bodirsky B, Delzeit R, Heckelei T, Heinzeller C, Klepper G, Lotze-Campen H, Lucht W, Mauser W, Popp A, Schaphoff S, Shamsaifar L (2010) Models and scenarios. White Paper Sustainable Land Management Programme/GLUES

Bailey R, Froggatt A, Wellesley L (2014) Livestock-climate change's forgotten sector. Global public opinion on meat and dairy consumption. The Royal Institute of International Affairs, Chatham House, London

Barker M, Lawrence W, Crozier S, Robinson S, Baird J, Margetts B, Cooper C (2009) Educational attainment, perceived control and the quality of women's diets. Appetite 52:631-636. doi:10.1016/ j.appet.2009.02.011

Barr SI, Chapman GE (2002) Perceptions and practices of selfdefined current vegetarian, former vegetarian, and nonvegetarian women. J Am Diet Assoc 102(3):354-360

Bastian B, Costello K, Loughnan S, Hodson G (2012) Don't mind meat? The denial of mind to animals used for human consumption. Pers Soc Psychol Bull 38(2):247-256. doi:10.1177/ 0146167211424291

Beardsworth AD, Bryman A (2004) Meat consumption and meat avoidance among young people. Br Food J 106(4):313-327. doi:10.1108/00070700410529573

Beardsworth AD, Keil ET (1991) Vegetarianism, veganism, and meat avoidance: recent trends and findings. Br Food J 93(4):19-24. doi:10.1108/00070709110135231
Bergmann I, von der Heidt T, Maller M (2010) Cognitive dissonance and individuals response strategies as a basis for audience segmentation to reduce factory farmed meat consumption. In: Russell-Bennett R, Rundle-Thiele S (eds) International nonprofit and social marketing conference, conference proceedings, Griffith University, Nathan, QLD, Brisbane, pp 32-35

Biesbroek GR, Klostermann JEM, Termeer CJAM, Kabat P (2013) On the nature of barriers to climate change adaptation. Reg Environ Change 13:1119-1129. doi:10.1007/s10113-013-0421-y

BMUB (2016) Klimaschutzplan 2050. Klimaschutzpolitische Grundsätze und Ziele der Bundesregierung. BMUB Entwurf 21. Juni 2016. Bundesministerium für Umwelt, Naturschutz, Bau und Reaktorsicherheit, Berlin

Bobić J, Cvijetić S, Barić IC, Šatalić Z (2012) Personality traits, motivation and bone health in vegetarians. Coll Antropol 36(3):795-800

Cassidy ES, West PC, Gerber JS, Foley JA (2013) Redefining agricultural yields: from tonnes to people nourished per hectare. Environ Res Lett 8:1-8. doi:10.1088/1748-9326/8/3/034015

Cassman KG (1999) Ecological intensification of cereal production systems: yield potential, soil quality, and precision agriculture. PNAS 96:5952-5959. doi:10.1073/pnas.96.11.5952

Cialdini RB, Reno RR, Kallgren CA (1990) A focus theory of normative conduct: recycling the concept of norms to reduce littering in public places. J Pers Soc Psychol 58(6):1015-1026. doi:10.1037/0022-3514.58.6.1015

Cordts A, Spiller A, Nitzko S, Grethe H, Duman N (2013) Imageprobleme beeinflussen den Konsum. Von unbekümmerten Fleischessern, Flexitariern und (Lebensabschnitts-)Vegetariern. FleischWirtschaft 7:59-63

Costa PT, McCrae RR (1992) Revised NEO Personality Inventory (NEO-PI-R) and NEO Five-Factor Inventory (NEO-FFI) professional manual. Psychological Assessment Resources, Odessa

Cramer W, Yohe GW, Auffhammer M, Huggel C, Molau U, da Silva Dias MAF, Solow A, Stone DA, Tibig L (2014) Detection and attribution of observed impacts. In: Field CB, Barros VR, Dokken DJ, Mach KJ, Mastrandrea MD, Bilir TE, Chatterjee M, Ebi KL, Estrada YO, Genova RC, Girma B, Kissel ES, Levy AN, MacCracken S, Mastrandrea PR, White LL (eds) Climate change 2014: impacts, adaptation, and vulnerability. Part A: global and sectoral aspects. Contribution of working group II to the fifth assessment report of the intergovernmental panel on climate change. Cambridge University Press, Cambridge, United Kingdom and New York, pp 979-1037

Dagevos H, De Bakker E (2015) Consumers as agents of change in transforming meat consumption patterns. In: Soeters K (ed) Meat, the future: how cutting meat consumption can feed billions more. Nicolaas G. Pierson Foundation, Amsterdam, pp 123-140

Dagevos H, Voordouw J (2013) Sustainability and meat consumption: is reduction realistic? Sustainability: science. Pract Policy 9(2):60-69

Darmon N, Drewnowski A (2008) Does social class predict diet quality? Am J Clin Nutr 87:1107-1117

Darnton A (2008) Reference report: an overview of behaviour change models and their uses. GSR behaviour change knowledge review. Centre for Sustainable Development, University of Westminster

Darnton A, Evans D (2013) Influencing behaviours. A technical guide to the ISM tool. The Scottish Government, Edinburgh

De Bakker E, Dagevos H (2012) Reducing meat consumption in today's consumer society: questioning the citizen-consumer gap. J Agric Environ Ethics 25:877-894. doi:10.1007/s10806-011$9345-\mathrm{z}$

de Boer J, Schösler H, Boersema JJ (2013) Climate change and meat eating: an inconvenient couple? J Environ Psychol 33:1-8. doi:10.1016/j.jenvp.2012.09.001 
Deckers J (2009) Vegetarianism, sentimental or ethical? J Agric Environ Ethics 22:573-597. doi:10.1007/s10806-009-9176-3

Dibb S, Fitzpatrick I (2014) Let's talk about meat: changing dietary behaviour for the 21st century. Eating Better, London

Edjabou LD, Smed S (2013) The effect of using consumption taxes on foods to promote climate friendly diets-The case of Denmark. Food Policy 39:84-96. doi:10.1016/j.foodpol.2012.12.004

Ericson T, Kjønstad BG, Barstad A (2014) Mindfulness and sustainability. Ecol Econ 104:73-79. doi:10.1016/j.ecolecon. 2014.04.007

FAO (2006) Livestock's long shadow. Environmental issues and options. Food and Agriculture Organization of the United States, Rome

FAOSTAT (2015) Statistics Division. Food and Agriculture Organization of the United States, Rome. http://faostat3.fao.org/faostatgateway/go/to/home/E. Accessed 4 June 2015

Fessler DMT, Arguello AP, Mekdara JM, Macias R (2003) Disgust sensitivity and meat consumption: a test of an emotivist account of moral vegetarianism. Appetite 41:31-41. doi:10.1016/S01956663(03)00037-0

Festinger L (1957) Theory of cognitive dissonance. Stanford University Press, Stanford

Fiddes N (1992) Meat. A natural symbol. Routledge, New York

Filippi M, Riccitelli G, Falini A, Di Salle F, Vuilleumier P, Comi G, Rocca MA (2010) The brain functional networks associated to human and animal suffering differ among omnivores, vegetarians and vegans. PLoS One 5(5):1-9. doi:10.1371/journal.pone. 0010847

Fischer D, Barth M (2014) Key competencies for and beyond sustainable consumption. An educational contribution to the debate. GAIA 23(S1):193-200. doi:10.14512/gaia.23.S1.7

Foley JA, Braumann KA, Cassidy ES, Gerber JS, Johnston M, Mueller ND, O'Connell C, Ray DK, West PC, Balzer C, Bennett EM, Carpenter SR, Hill J, Monfreda C, Polasky S, Rockström J, Sheehan J, Siebert S, Tilman D, Zaks DPM (2011) Solutions for a cultivated planet. Nature 478:337-342. doi:10.1038/ nature 10452

Fox N, Ward K (2007) Health, ethics and environment: a qualitative study of vegetarian motivations. Appetite 50:422-429. doi:10. 1016/j.appet.2007.09.007

Furst T, Connors M, Bisogni CA, Sobal J, Winter-Falk L (1996) Food choice: a conceptual model of the process. Appetite 26:247-266. doi:10.1006/appe.1996.0019

Garnett T, Wilkes A (2014) Appetite for change. Social, economic and environmental transformations in China's food system. Food Climate Research Network, Oxford

Garnett T, Röös E, Little D (2015a) Lean, green, mean, obscene...? What is efficiency? And is it sustainable? Animal production and consumption reconsidered. Food Climate Research Network, Oxford

Garnett T, Mathewson S, Angelides P, Borthwick F (2015b) Policies and actions to shift eating patterns: What works? A review of the evidence of the effectiveness of interventions aimed at shifting diets in more sustainable and healthy directions. Food Climate Research Network (FCRN) and Chatham House, Oxford

Gerber PJ, Steinfeld H, Henderson B, Mottet A, Opio C, Dijkman J, Falcucci A, Tempio G (2013) Tackling climate change through livestock. A global assessment of emissions and mitigation opportunities. Food and Agriculture Organization of the United States, Rome

Gifford R, Nilsson A (2014) Personal and social factors that influence pro-environmental concern and behaviour: a review. Int $\mathbf{J}$ Psychol 49(3):141-157. doi:10.1002/ijop.12034

Girod B, van Vuuren DP, Hertwich EG (2014) Climate policy through changing consumption choices: options and obstacles for reducing greenhouse gas emissions. Global Environ Change 25:5-15. doi:10.1016/j.gloenvcha.2014.01.004

Godfray HCJ, Beddington JR, Crute IR, Haddad L, Lawrence D, Muir JF, Pretty J, Robinson S, Thomas SM, Toulmin C (2010) Food security: the challenge of feeding 9 billion people. Science 327:812-818. doi:10.1126/science. 1185383

Goldberg LR, Stryker LA (2002) Personality traits and eating habits: the assessment of food preferences in a large community sample. Personal Individ Differ 32:49-65

Graça J, Oliveira A, Calheiros MM (2015) Meat, beyond the plate: data-driven hypotheses for understanding consumer willingness to adopt a more plant-based diet. Appetite 1(90):80-90. doi:10. 1016/j.appet.2015.02.037

Greenhalgh T, Peacock R (2005) Effectiveness and efficiency of search methods in systematic reviews of complex evidence: audit of primary sources. BMJ 331:1064-1065. doi:10.1136/bmj. 38636.593461 .68

Grunert KG, Brunso K, Bredahl L, Bech AC (2001) Food-related lifestyle: a segmentation approach to European food consumers. In: Frewer LJ, Risvik E, Schifferstein H (eds) Food, people and society. A European perspective of consumers' food choices. Springer, Berlin, pp 211-231

Harmon-Jones E, Mills J (1999) Cognitive dissonance: perspectives on a pivotal theory in social psychology. American Psychological Association, Washington DC

Haverstock K, Forgays DK (2012) To eat or not to eat. A comparison of current and former animal product limiters. Appetite 58(3):1030-1036. doi:10.1016/j.appet.2012.02.048

Hedenus F, Wirsenius S, Johansson DJA (2014) The importance of reduced meat and dairy consumption for meeting stringent climate change targets. Clim Change 124(1-2):79-91. doi:10. 1007/s10584-014-1104-5

Heinrich-Böll-Foundation (2014) Meat atlas. Facts and figures about the animals we eat. Berlin

Higgs S (2015) Social norms and their influence on eating behaviours. Appetite 86:38-44. doi:10.1016/j.appet.2014.10.021

IFES (2013) Studie zum Thema Tierschutz. Institute for Empirical Social Studies, Vienna; quote in Vegan Society Austria. http:// archiv.veggie-planet.at/warumvegan/tierrechte/Veggie.pdf. Accessed 5 June 2015

IKEA Group (2015) Sustainability report. Älmhult

INRA, CIRAD (2016) Agrimonde-Terra foresight study on 'Land use and food security in 2050'. French National Institute for Agricultural Research (INRA) and French Agricultural Research Centre for International Development (CIRAD), Paris

IPCC (2014) Climate Change 2014. Mitigation of climate change. Summary for policymakers and technical summary. Part of the Working Group III. Contribution to the Fifth Assessment Report of the Intergovernmental Panel on Climate Change. Intergovernmental Panel on Climate Change, Geneva

Janda S, Trocchia PJ (2001) Vegetarianism: toward a greater understanding. Psychol Mark 18(12):1205-1240

Jones NRV, Conklin AI, Suhrcke M, Monsivais P (2014) The growing price gap between more and less healthy foods: analysis of a novel longitudinal UK dataset. PLoS One 9(10):1-7. doi:10. 1371/journal.pone.0109343

Joy M (2005) Humanistic psychology and animal rights: reconsidering the boundaries of the humanistic ethic. J Humanist Psychol 45:106-130. doi:10.1177/0022167804272628

Joy M (2011) Why we love dogs, eat pigs and wear cows. An introduction to carnism. Conari Press, San Francisco

Joyce A, Dixon S, Comfort J, Hallet J (2012) Reducing the environmental impact of dietary choice: perspectives from a behavioural and social change approach. J Environ Public Health 2012:1-7. doi:10.1155/2012/978672 
Kaiser FG, Shimoda TA (1999) Responsibility as a predictor of ecological behaviour. J Environ Psychol 19:243-253. doi:10. 1006/jevp.1998.9123

Keller M, Kretschmer J (2012) Instrumente im Sinne einer nachhaltigen, klimafreundlichen Fleischproduktion. Eine Untersuchung im Auftrag von MISEREOR. Bischöfliches Hilfswerk MISEREOR e. V., Aachen

Keller C, Siegrist M (2015) Does personality influence eating styles and food choices? Direct and indirect effects. Appetite 84:128-138. doi:10.1016/j.appet.2014.10.003

Kollmuss A, Agyeman J (2002) Mind the gap: why do people act environmentally and what are the barriers to pro-environmental behavior? Environ Educ Res 8(3):239-260. doi:10.1080/ 13504620220145401

Laestadius LI, Neff RA, Barry CL, Frattaroli S (2013) Meat consumption and climate change: the role of non-governmental organizations. Clim Change 120:25-38. doi:10.1007/s10584-013-0807-3

Laestadius LI, Neff RA, Barry CL, Frattaroli S (2014) We don't tell people what to do: an examination of the factors influencing NGO decisions to campaign for reduced meat consumption in light of climate change. Global Environ Change 29:32-40. doi:10.1016/j.gloenvcha.2014.08.001

Lanfranco BA, Rava C (2014) Household demand elasticities for meat products in Uruguay. Span J Agric Res 12(1):15-28. doi: $10.5424 / \mathrm{sjar} / 2014121-4615$

Lea E, Worsley A (2001) Influences on meat consumption in Australia. Appetite 36:127-136. doi:10.1006/appe.2000.038

Lea E, Worsley A (2008) Australian consumers' food-related environmental beliefs and behaviours. Appetite 50(2-3):207-214. doi:10.1016/j.appet.2005.07.012

Lea EJ, Crawford D, Worsley A (2006) Consumers' readiness to eat a plant-based diet. Eur J Clin Nutr 60:342-351. doi:10.1038/sj. ejcn. 1602320

Leahy E, Lyons S, Tol RSJ (2010) An estimate of the number of vegetarians in the world. ESRI working paper no. 340. The Economic and Social Research Institute, Dublin

Lewin K (1951) Field theory in social sciences. Selected papers on group dynamics. Harper \& Row, New York

Lindeman M, Väänänen M (2000) Measurement of ethical food choice motives. Appetite 34:55-59. doi:10.1006/appe.1999.0293

Loewenstein GF, Hsee CK, Weber EU, Welch N (2001) Risk as feelings. Psychol Bull 127(2):267-286. doi:10.1037//0033-2909. 127.2.267

Loughnan S, Haslam N, Bastian B (2010) The role of meat consumption in the denial of moral status and mind to meat animals. Appetite 55:156-159. doi:10.1016/j.appet.2010.05.043

Loughnan S, Bastian B, Haslam N (2014) The psychology of eating animals. Curr Dir Psychol Sci 23:104-108. doi:10.1177/ 0963721414525781

Lovera M (2015) Meat from a landscape under threat: testimonies of the impacts of unsustainable livestock and soybean production in Paraguay. Global Forest Coalition and Brighter Green, Asunción

Machovina B, Feeley KJ, Ripple WJ (2015) Biodiversity conservation: the key is reducing meat consumption. Sci Total Environ 536:419-431. doi:10.1016/j.scitotenv.2015.07.022

Magliocca NR, Rudel TK, Verburg PH, McConnell WJ, Mertz O, Gerstner K, Heinimann A, Ellis EC (2015) Synthesis in land change science: methodological patterns, challenges, and guidelines. Reg Environ Change 15:211-226. doi:10.1007/s10113014-0626-8

Mäkiniemi J-P, Vainio A (2014) Barriers to climate-friendly food choices among young adults in Finland. Appetite 74:12-19. doi:10.1016/j.appet.2013.11.016

Mäkiniemi J-P, Pirttilä A-M, Pieri M (2011) Ethical and unethical food. Social representations among Finnish, Danish and Italian students. Appetite 56:495-502. doi:10.1016/j.appet.2011.01.023
Masset G, Vieux F, Verger EO, Soler L-G, Touazi D, Darmon N (2014) Reducing energy intake and energy density for a sustainable diet: a study based on self-selected diets in French adults. Am J Clin Nutr 99:1460-1469. doi:10.3945/ajen.113. 077958

McKenzie-Mohr D, Smith W (1999) Fostering sustainable behavior: an introduction to community-based social marketing. New Society, Gabriola Island

Meier T, Christen O (2013) Environmental impacts of dietary recommendations and dietary styles: germany as an example. Environ Sci Technol 47(2):877-888. doi:10.1021/es302152v

Nath J (2010) Gendered fare? A qualitative investigation of alternative food and masculinities. J Sociol. doi:10.1177/ 1440783310386828

Noppers EH, Keizer K, Bolderdijk JW, Steg L (2014) The adoption of sustainable innovations: driven by symbolic and environmental motives. Global Environ Change 25:52-62

O'Riordan T, Stoll-Kleemann S (2015) The challenges of changing dietary behavior toward more sustainable consumption. Environment 57(5):4-13

Peattie K (2010) Green consumption: behavior and norms. Annu Rev Environ Resour 35:195-228. doi:10.1146/annurev-environ032609-094328

Piazza J, Ruby MB, Loughnan S, Loung M, Kulik J, Watkins HM, Seigerman M (2015) Rationalizing meat consumption: the 4Ns. Appetite 91:114-128. doi:10.1016/j.appet.2015.04.011

Pimentel D (1996) Green revolution agriculture and chemical hazards. Sci Total Environ 188(1):86-98. doi:10.1016/00489697(96)05280-1

Pimentel D, Pimentel M (2003) Sustainability of meat-based and plantbased diets and the environment. Am J Clin Nutr 78:660-663

Pribis P, Pencak RC, Grajales T (2010) Beliefs and attitudes toward vegetarian lifestyle across generations. Nutrients 2:523-531. doi:10.3390/nu2050523

Rao M, Afshin A, Singh G, Mozaffarian D (2013) Do healthier foods and diet patterns cost more than less healthy options? A systematic review and meta-analysis. BMJ Open 3:1-17. doi:10. 1136/bmjopen-2013-004277

Rauschmayer F, Omann I (2012) Transition to sustainability: not only big, but deep. GAIA 21(4):266-268

Richardson NJ, Shepherd R, Elliman NA (1993) Current attitudes and future influences on meat consumption in the UK. Appetite 21:41-51

Ritson C, Petrovici D (2001) The economics of food choice: Is price important? In: Frewer LJ, Risvik E, Schifferstein H (eds) Food, people and society. A European perspective of consumers' food choices. Springer, Berlin, pp 339-364

Rizzo NS, Jaceldo-Siegl K, Sabate J, Fraser GE (2013) Nutrient profiles of vegetarian and nonvegetarian dietary patterns. J Acad Nutr Diet 113(12):1610-1619. doi:10.1016/j.jand.2013.06.349

Rothgerber H (2014a) Efforts to overcome vegetarian-induced dissonance among meat eaters. Appetite 79:32-41. doi:10. 1016/j.appet.2014.04.003

Rothgerber H (2014b) A comparison of attitudes toward meat and animals among strict and semi-vegetarians. Appetite 72:98-105. doi:10.1016/j.appet.2013.10.002

Ruby MB, Heine SJ (2011) Meat, morals, and masculinity. Appetite 56:447-450. doi:10.1016/j.appet.2011.01.018

Salonen AO, Helne TT (2012) Vegetarian diets: a way towards a sustainable society. J Sustain Dev. doi:10.5539/jsd.v5n6p10

Santos MLS, Booth DA (1996) Influences of meat avoidance among British students. Appetite 27:197-205

Schösler H, de Boer J, Boersema JJ (2012) Can we cut out the meat of the dish? Constructing consumer-oriented pathways towards meat substitution. Appetite 58:39-47. doi:10.1016/j.appet.2011. 09.009 
Schösler H, de Boer J, Boersema JJ, Aiking H (2015) Meat and masculinity among young Chinese, Turkish and Dutch adults in the Netherlands. Appetite 89:152-159. doi:10.1016/j.appet.2015. 02.013

Schwartz SH (1977) Normative influences on altruism. Adv Exp Soc Psychol 10:221-279. doi:10.1016/S0065-2601(08)60358-5

Segal E (2014) Is Israel going to be the first vegan nation? The Vegan Woman. http://www.theveganwoman.com/israel-going-firstvegan-nation/. Accessed 5 June 2015

Sexton RJ (2013) Market power, misconceptions, and modern agricultural markets. Am J Agric Econ 95(2):209-219. doi:10. 1093/ajae/aas 102

Shepherd R (2001) Does taste determine consumption? Understanding the psychology of food choice. In: Frewer LJ, Risvik E, Schifferstein H (eds) Food, people and society. A European perspective of consumers' food choices. Springer, Berlin, pp 117-130

Singer P (1981) The expanding circle. Ethics, evolution, and moral progress. Princeton University Press, Princeton

Sneijder P, te Molder H (2009) Normalizing ideological food choice and eating practices. Identity work in online discussions on veganism. Appetite 52:621-630. doi:10.1016/j.appet.2009.02. 012

Stern PC (2000) Toward a coherent theory of environmentally significant behaviour. J Soc Issues 56:407-426. doi:10.1111/ 0022-4537.00175

Stoll-Kleemann S (2014) Fleischkonsum im 21. Jahrhundert-ein Thema für die humanökologische Forschung. GAIA 23(4):366-368. doi:10.14512/gaia.23.4.18

Stoll-Kleemann S, O'Riordan T (2015) The sustainability challenges of our meat and dairy diets. Environment 57(3):34-48. doi:10. $1080 / 00139157.2015 .1025644$

Sunderland TCH (2011) Food security: why is biodiversity important? Int For Rev 13(3):265-274. doi:10.1505/ 146554811798293908

The Guardian (2016) China's plan to cut meat consumption by $50 \%$ cheered by climate campaigners. https://www.theguardian.com/ world/2016/jun/20/chinas-meat-consumption-climate-change. Accessed 9 August 2016

Thøgerson J (2014) Unsustainable consumption. Basic causes and implications for policy. Eur Psychol 19(2):84-95. doi:10.1027/ 1016-9040/a000176

Thrupp LA (2000) Linking agricultural biodiversity and food security: the valuable role of agrobiodiversity for sustainable agriculture. Int Aff 76(2):265-281. doi:10.1111/1468-2346. 00133

Tilman D, Clark M (2014) Global diets link environmental sustainability and human health. Nature 515:518-522. doi:10.1038/ nature 13959

Tilman D, Cassman KG, Matson PA, Naylor R, Polasky S (2002) Agricultural sustainability and intensive production practices. Nature 418:671-677. doi:10.1038/nature01014

Tilman D, Balzer C, Hill J, Befort BL (2011) Global food demand and the sustainable intensification of agriculture. PNAS 108(50):20260-20264. doi:10.1073/pnas.1116437108

Tobler C, Visschers VHM, Siegrist M (2011) Eating green. Consumers' willingness to adopt ecological food consumption behaviors. Appetite 57:674-682. doi:10.1016/j.appet.2011.08. 010

Triandis HC (1977) Interpersonal Behaviour. Brook/Cole, Monterey

Tscharntke T, Clough Y, Wanger TC, Jackson L, Motzke I, Perfecto I, Vandermeer J, Whitbread A (2012) Global food security, biodiversity conservation and the future of agricultural intensification. Biol Conserv 151:53-59. doi:10.1016/j.biocon.2012.01. 068

Tucker CA (2014) The significance of sensory appeal for reduced meat consumption. Appetite 81:168-179. doi:10.1016/j.appet. 2014.06.022

Vartanian LR (2015) Impression management and food intake. Current directions in research. Appetite 86:74-80. doi:10.1016/j. appet.2014.08.021

Verain M, Dagevos H, Antonides G (2015) Flexitarianism: a range of sustainable food styles. In: Reisch LA, Thogersen J (eds) Handbook of research on sustainable consumption. Edward Elgar Publishing, Cheltenham, pp 209-223

Verbeke W (2008) Impact of communication on consumers' food choices. Proc Nutr Soc 67:281-288. doi:10.1017/ S0029665108007179

Vieux F, Soler L-G, Touazi D, Darmon N (2013) High nutritional quality is not associated with low greenhouse gas emissions in self-selected diets of French adults. Am J Clin Nutr 97:569-583. doi:10.3945/ajcn.112.035105

WBGU (2011) World in transition. A social concept for sustainability. Flagship Report. German Advisory Council on Global Change, Berlin

West PC, Gerber JS, Engstrom PM, Mueller ND, Brauman KA, Carlson KM, Cassidy ES, Johnston M, MacDonald GK, Ray DK, Siebert S (2014) Leverage points for improving global food security and the environment. Science 345:325-328. doi:10. 1126/science. 1246067

Westhoek H, Rood T, van den Berg M, Janse J, Nijdam D, Reudink M, Stehfest E (2011) The protein puzzle. The consumption and production of meat, dairy and fish in the European Union. PBL Netherlands Environmental Assessment Agency, The Hague

Wezemael LV, Verbeke W, deBarcellos MD, Scholderer J, PerezCueto F (2010) Consumer perceptions of beef healthiness: results from a qualitative study in four European countries. BMC Public Health 10:342-352. doi:10.1186/1471-2458-10-342

Wiig K, Smith C (2008) The art of grocery shopping on a food stamp budget: factors influencing the food choices of low-income women as they try to make ends meet. Public Health Nutr 12(19):1726-1734. doi:10.1017/S1368980008004102

Wirsenius S, Azar C, Berndes G (2010) How much land is needed for global food production under scenarios of dietary changes and livestock productivity increases in 2030? Agric Syst 103:621-638. doi:10.1016/j.agsy.2010.07.005

Withana S, ten Brink P, Franckx L, Hirschnitz-Garbers M, Mayeres I, Oosterhuis F, Porsch L (2012) Study supporting the phasing out of environmentally harmful subsidies. A report by the Institute for European Environmental Policy (IEEP), final report. Institute for Environmental Studies-Vrije Universiteit (IVM), Ecologic Institute and VITO for the European Commission-DG Environment, Brussels

WWF (2014) Living Planet Report 2014 Species and spaces, people and places. World Wildlife Fund International, Gland

Wyker BA, Davison KK (2010) Behavioral change theories can inform the prediction of young adult's adoption of a plant-based diet. J Nutr Educ Behav 42(3):168-177. doi:10.1016/j.jneb.2009. 03.124

YouGov (2014) Wer will's schon vegan? Aktuelle Ernährungsvorlieben und Lieblingsmarken in Deutschland 2014-Typ für Typ. Cologne 